\title{
Foundation Of City Tourism Information Service Model Based On Internet Of Things
}

\author{
Xiao Zhou*, Yuanyuan Pang ${ }^{\dagger}$, Sen Li*, Wei Wang*, Wei Jiao*, Dongming Zeng* \\ *Information Engineering University, Zhengzhou 450001, China \\ ${ }^{\dagger} 61206$ Troops, Beijing 100088, China
}

Keywords: city tourism; information service; Internet of Things; system design and develop

\begin{abstract}
On analyzing Internet of Things, this paper brings forward the city tourism information service model. It designs the multiclass structure of the model which contains threes layers and sub-layers, on which base, related databases and subdatabases are created to store tourism data information. And then it develops the city tourism information service system and analyzes the main functions of the system, of which, the system can output selected tourism information, tourism map and tourism route to provide service for tourists.
\end{abstract}

\section{Introduction}

Before tourists arriving at an unfamiliar city, they should know about tourism information of the city, especially the important and typical urban scenic spots. And then they choose proper quantity and category of scenic spots depending on their own interests in order to do rational tour project. Nowadays, Tourists get city tourism information by surfing Internet, purchasing books, inquiring travel agency, etc. These methods are dispersive, and no tourism geographic information system for a city to manage and inquire city scenic spot information is specially developed, man-machine interaction is not realized, either. Aiming at the problem, this paper brings forward city tourism information service model based on Internet of Things[1,2,3]. Take Zhengzhou as example, it develops tourism information collection interface and tourism information processing interface. Tourists can obtain, inquire, choose and input tourism information. Meanwhile, they can obtain tourism map and route decision support.

\section{City tourism information service model based on Internet of Things}

\subsection{Structure of Internet of Things}

Internet of Things contains perception layer, network layer and application layer. Perception layer function is data acquisition, which obtains data information by sensor, RFID, twodimension code technology from natural world. After preprocessing, data is transmitted within short distance and small range and stored in database built in perception layer. Network layer function is data transmission and share, which is operated by Internet or local area network to realize safe and steady transmission[4,5,6]. Application layer function is data processing and dissemination, which uses cloud computing, fuzzy recognition, etc. to dispose accepted data and store, manage and apply data information. Finally it provides service to client. Figure. 1 is the structure of Internet of Things.

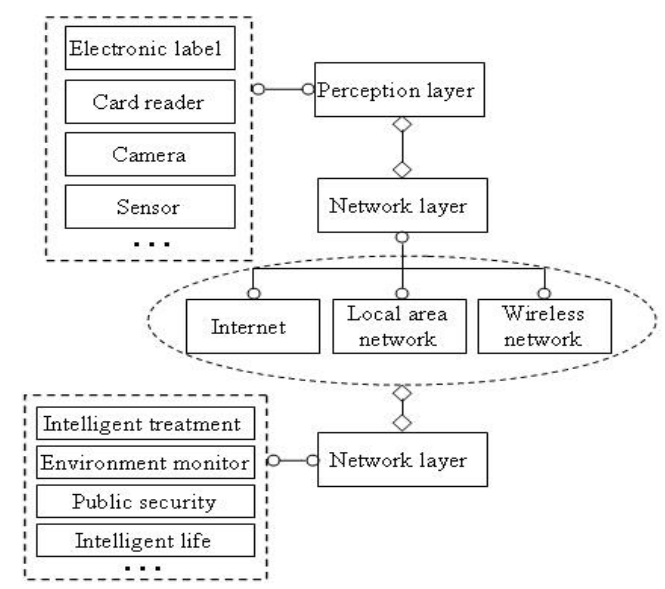

Figure 1: Structure of Internet of Things

\subsection{City tourism information service model based on} Internet of Things

City tourism contains many aspects. According to tourists needs, it includes three aspects. They are, first one, city scenic spot information, second one, scenic spot buffer service information, third one, scenic spot interval service information. City scenic spot information contains the attribute information and spatial information of typical urban scenic spots. Scenic spot buffer service information contains service information within some range of the scenic spot. Scenic spot interval service information contains related service information of the scenic spot.

Different tourists have various interests, for instance, the elder are fond of park and green field, the youngsters like playground yard and shopping mall. As to a single tourist, choosing most interested scenic spots is the precondition to get maximum motive benefits[7,8]. Take Zhengzhou city tourism scenic spots as data resource. Apply perception layer as data collection layer (Level I ), Internet network as data transmission layer (Level II ), application layer as data processing layer (Level III) to set city tourism information 
service model based on Internet of Things. Each layer contains sub-layer.

- Level I $=\{$ Layer 1 : Tourism attribute information; Layer2: Tourism spatial information; Layer3 : Selected information management $\}$

- Level II $=\{$ Layer 1 : Information collection terminal; Layer2: Information transmission network; Layer3: Information reception terminal $\}$

- Level III =\{Layer1: Tourism information output; Layer2: Tourism map output; Layer3: Tourism route decision support $\}$

The city tourism information service model based on Internet of Things is set up as Figure. 2 shows.

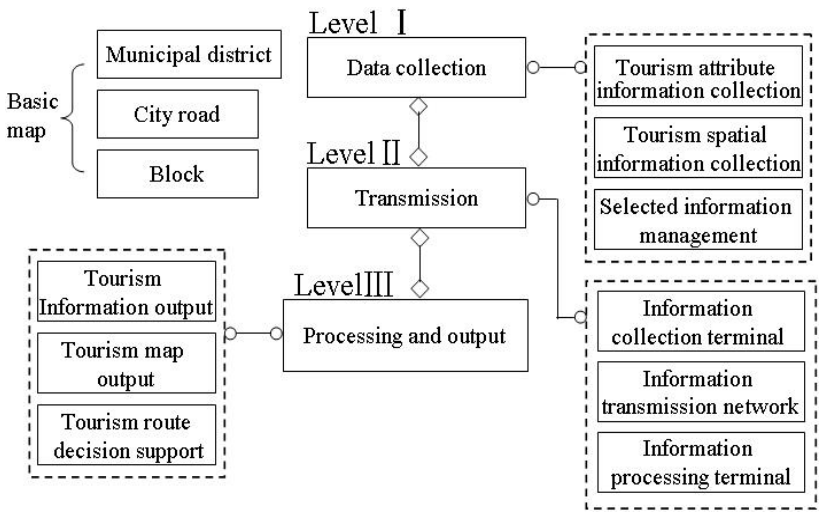

Figure 2: City tourism information service model based on Internet of Things

Each layer function is as follows.

1) Data collection layer (Level I ): Realize the selection of city scenic spot and the high streets around. Obtain scenic spot attribute data and spatial data. Use database to manage selected data.

2) Data transmission layer (Level II ): Provide the hardware and software environment of data collection, storage, transmission and processing.

3) Data processing layer (Level III): Realize the output of selected scenic spot information, tourism map and tourism route decision support.

\section{Database information management model}

Different data information of the model is stored in multiclass databases. Firstly, tourism information collection interface is designed and developed. This interface stores Zhengzhou urban scenic spots' attribute data, spatial data and selected tourism information. The first category tourism information management database (Database I ) is used to store and manage all the tourism information, under which, the sub-class database includes several sun-database. The second category tourism information processing database (Database II )is used to store processed tourism information, under which, the sub-class database includes several sundatabase. The two databases include the following subdatabases, whose structure is shown in Figure.3.
- Database I $=\{$ Sub-database 1 : Tourism attribute information database; Sub-database2: Tourism spatial information database; Sub-database3: Selected information database $\}$

- Database II $=\{$ Sub-database 1 : Tourism information output library; Sub-database2: Tourism map library; Sub-database3: Tourism route library\}

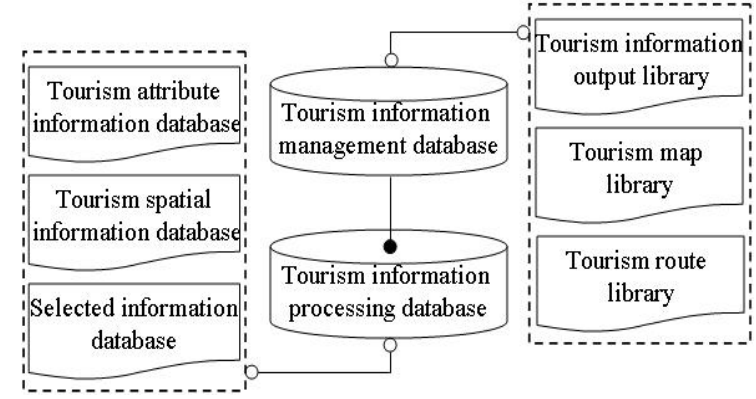

Figure 3: Database information management model

Each database's main function is as follows.

1) Tourism information management database (Database I ): System stores tourism scenic spot information, including attribute and spatial information, and stores selected information.

2) Tourism information processing database (Database II ): System stores processed information, including selected scenic spot information, tourism map and tourism route.

\section{System developing and function analysis}

\subsection{System developing}

The hardware environment is:

- 1 lab DELL PowerEdge 12G R720 server, 12G computer internal storage

- 500G high-capacity hard disk

- Output facility is Cannon iP2780 printer.

The software environment is:

- Windows 7 operating system,

- Visual Studio 2015 programming environment

- Access database

- MapInfo map design software.

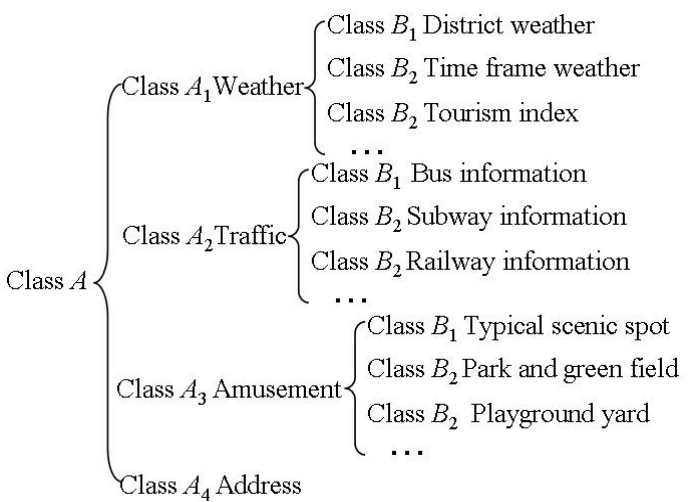

Figure 4: Tourism information and sub-class relationship 


\begin{tabular}{|c|c|c|c|c|}
\hline $\begin{array}{c}\text { Class } \\
\text { A }\end{array}$ & Weather & Traffic & Amusement & Address \\
\hline $\begin{array}{c}\text { Class } \\
\text { B }\end{array}$ & $\begin{array}{l}\text { District } \\
\text { Time } \\
\text { frame } \\
\text { Tourism } \\
\text { index / } \\
\text { Etc. }\end{array}$ & $\begin{array}{c}\text { Subway } \\
\text { Bus } \\
\text { Railway } \\
\text { Airline / } \\
\text { Etc. }\end{array}$ & $\begin{array}{l}\text { Park and } \\
\text { green field } \\
\text { Typical } \\
\text { scenic spot } \\
\text { Playground } \\
\text { yard } \\
\text { Shopping } \\
\text { mall / Etc. }\end{array}$ & $\begin{array}{c}\text { Erqi District } \\
\text { Zhongyuan } \\
\text { District } \\
\text { Huiji District } \\
\text { Jinshui } \\
\text { District } \\
\text { Guancheng } \\
\text { District } \\
\text { High-tech } \\
\text { zone } \\
\text { Zhongmou } \\
\text { county / Etc. }\end{array}$ \\
\hline $\begin{array}{c}\text { Class } \\
\text { C }\end{array}$ & $\begin{array}{c}\text { Erqi } \\
\text { Zhongyua } \\
\mathrm{n} \\
\text { Huiji } \\
\text { Jinshui } \\
\text { Guanchen } \\
\text { g } \\
\text { High-tech } \\
\text { zone } \\
\text { Zhongmo } \\
\text { u/ Etc. } \\
\text { 1-2h }\end{array}$ & $\begin{array}{l}\text { Subway } \\
\text { Line 1 } \\
\text { Subway } \\
\text { Line } 2 \\
\text { Bus } \\
\text { Line 1, } \\
\text { Bus } \\
\text { Line 2, } \\
\text { etc. } \\
\text { Train } \\
\text { number } \\
\text { Railway } \\
\text { station, } \\
\text { etc. } \\
\text { Eastern } \\
\text { Airlines } \\
\text {, ets. }\end{array}$ & $\begin{array}{c}\text { Renmin park } \\
\text { Bishagang } \\
\text { park } \\
\text { Zijingshan } \\
\text { park,etc. } \\
\text { Yellow river } \\
\text { view } \\
\text { Zhengzhou } \\
\text { museum } \\
\text { Erqi } \\
\text { memorial,et } \\
\text { c } \\
\text { Bar street } \\
\text { Century } \\
\text { park,etc. }\end{array}$ & $\begin{array}{l}\text { Specific road } \\
\text { around the } \\
\text { scenic spots. }\end{array}$ \\
\hline
\end{tabular}

Table 1: Scenic spot data resource

According to the founded model, tourism information collection interface and processing interface are designed and developed. Divide Zhengzhou urban scenic spots into Weather, Traffic and Amusement as three attribute information as well as scenic spot address as spatial information, which is set as class $A$, on which basis, Class $B$ is set. For instance, amusement includes typical scenic spot, park and green field, playground yard and shopping mall. On the basis of class $B$, Class $C$ is set. For instance, park and green field includes Renmin park, Bishagang park, Lvcheng square, etc. Tourism information and sub-class relationship is shown in Figure.4. Selected information will be transmitted to processing layer through network layer. Information processing layer processes the received information and feeds back to tourists. Feedback information includes scenic spot introduction, tourism map and tourism route, etc[9]. The scenic spot data resource used to set up the database is shown in the following Table 1. Tourism information collection interface and information processing interface are developed as Figure. 5 shows.

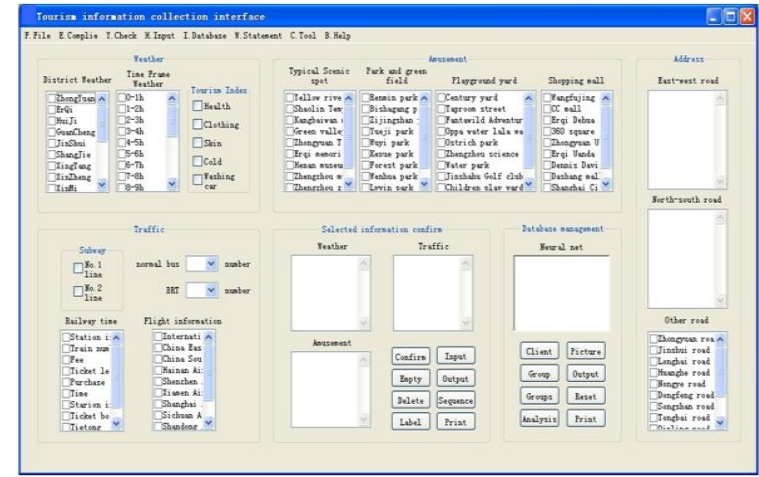

(1) Tourism information collection interface

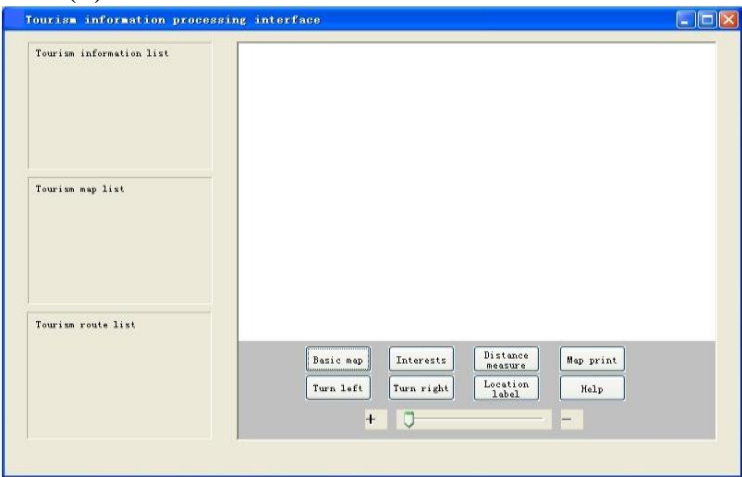

(2) Tourism information processing interface

Figure 5: Tourism information collection and processing interface

\subsection{System function analysis}

\begin{tabular}{|c|c|c|}
\hline & Function key & Function \\
\hline \multirow{11}{*}{$\begin{array}{l}\text { Selected } \\
\text { information } \\
\text { confirm }\end{array}$} & Confirm & Confirm tourism information \\
\hline & Empty & Empty tourism information \\
\hline & Delete & Delete any tourism \\
\hline & DCICL & information \\
\hline & Label & Important information \\
\hline & & charted on the map \\
\hline & Input & $\begin{array}{c}\text { Input other complementary } \\
\text { information }\end{array}$ \\
\hline & Output & Output tourism information \\
\hline & Sequence & Sequence tourism \\
\hline &  & information rely on interests \\
\hline & Print & Print the list \\
\hline \multirow{7}{*}{$\begin{array}{c}\text { Database } \\
\text { management }\end{array}$} & $\begin{array}{l}\text { Client } \\
\text { Group }\end{array}$ & $\begin{array}{c}\text { Client database management } \\
\text { Single group database } \\
\text { management }\end{array}$ \\
\hline & Groups & Groups database management \\
\hline & Analysis & Spatial database management \\
\hline & Picture & Neural net picture charting \\
\hline & Output & Output neural net picture \\
\hline & Reset & Reset database \\
\hline & Print & Print database information \\
\hline
\end{tabular}

Table 2: Tourism information collection interface function keys and functions 
As Figure.5(1), in the tourism information collection interface, "Weather", "Amusement", "traffic" belong to attribute information provided for tourists. "Address" is spatial information. Road information is shown by scenic spots selected by tourists. Needed road information can be added. "Selected information confirm" is the visualized display of selected information. Add, delete, label, etc. can be operated. "Database management" is used to store selected scenic spot information. Analysis, reset, print, etc. can also be operated. The function keys and theirs function of Tourism information collection interface are shown in Table 2.

As Figure 5(2), "tourism information list" displays selected scenic spot information. Choose specific scenic spot, window is drawn out to display related information and service information around. "Tourism map list" displays map names created automatically by the system according to the selected scenic spots. Choose specific map, the map can be displayed in the right window, including scenic spot, service around, road information, etc. Distance measure, interests display, map print, map zoom, etc. can be operated. "Tourism route list" displays optimal tourism routes automatically programmed by the system. Choose specific route, window is drawn out to display information and service information around. The function keys and functions of Tourism information processing interface are shown in Table 3.



Table 3: Tourism information processing interface function keys and functions

\section{Conclusion}

On the analysis of Internet of Things, this paper brings forward the city tourism information service model and designs the system, which includes tourism information collection interface and tourism information processing interface. Through system structure founding and multi-class database founding to realize tourism information collecting and processing. Tourists can select favorite scenic spots and obtain related information as well as information around. System can automatically create tourism map and route for tourist, which provides convenient service and decision support for tourist who aims to have a city trip.

\section{Acknowledgements}

Here I appreciate the help provided by all my team members. We finished the work and paper together. Thanks for all.

\section{References}

[1] ZHAO X M, SUN Q X, DING Y. Passenger choice behavior for regional rail transit under express/local operation with overtaking. Journal of Transportation Systems Engineering and Information Technology, 2016, 16(5), p.104-109.

[2] WANG C Y, QU H L. Tourist motive, destination image and tourism expectation. Tourism Tribune, 2013 , 28(6), p.26-34.

[3] LONG X Q, WANG J J, ZHOU B. Travelers dynamic decision making based on decision field theory. Journal of Transportation Systems Engineering and Information Technology, 2016, 16(1), p.12-18.

[4] Nicolau J L, Ma's F J. The influence of distance and prices on the choice of tourist destinations : the moderating role of motivations. Tourism Management, 2006, 27, p.982-996.

[5] LI X J, CUI S S, ZHANG K. Neural net method of best tourism route choice. Transportation and Computer, 2006, 24(5), p.103-106.

[6] Vansteenwegen P, Van Oudheusden D( 2007). The mobile tourist guide: an OR opportunity. OR Insight, 20( 3) , p.21-27.

[7] Smith V K, Krutilla J V ( 1974 ) . A simulation model for the management of low density recreation areas. Journal of Environmental Economics and Management, 1( 3), p.187-201.

[8] Skov-Petersen H( 2008) . The role of agent-based simulation in recreational management and planning recreational management and planning.A//R aschi $\mathrm{A}$, Trampetti S. Management for protection and sustainable development. Montecatini: Consiglio Nationale della Ricerche, 33-39.

[9] Itami R, R aulings R, Maclarcn G, et al. ( 2003) . R BSim 2: Simulation the complex interactions between human movement and the outdoor recreation environment. Journal of Nature Conservation, 11(4), p.278-286. 